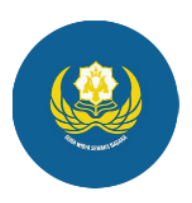

\title{
Stimulation of Awig-Awig in Character Development and Human Resources Improvement in the Traditional Village of Penglipuran
}

\author{
I G. A. Agung Dewi Kurnia Uthami ${ }^{1}$ \\ A.A.N. Eddy Supriyadinata Gorda ${ }^{2}$ \\ Universitas Pendidikan Nasional, Bali, Indonesia ${ }^{1,2}$ \\ Email: agungdewikurnia12@gmail.com ${ }^{l}$ eddy_supriyadinata@yahoo.com ${ }^{2}$
}

Published: 17/03/2021

How to cite (in APA style):

Uthami, I. \& Gorda, A. (2021). Stimulation of Awig-Awig in Character Development and Human Resources Improvement in the Traditional Village of Penglipuran. Jurnal Ekonomi dan Bisnis Jagaditha, 8 (1), 1-14. doi: https://10.22225/jj.8.1.2738.1-14

\begin{abstract}
This study aims to examine awig-awig stimulation in developing character and improving human resources in Traditional Village of Penglipuran. A case study was conducted in the village. To answer research questions, interviews were conducted with village policy makers who have a good understanding of awig-awig and villagers who understand awig-awig and live under the awig-awig shade. This study uses purposive sampling. The data analysis was carried out in four steps, namely data collection, data reduction, data presentation and conclusion drawing/ verification. Validity tests of the research are credibility test, transferability test, dependability test, and confirmability test. This research reveals that stimulation of awigawig of the Traditional Village of Penglipuran is (1) able to shape the character of the entire community according to Hindu religious values; (2) able to foster the village tourism by developing human resources based on local wisdom without being eroded by globalization, and (3) binding customary rules to make the community of the Penglipuran village remain firm and obedient to awig-awig in conjunction with the concept of Tri Hita Karana.
\end{abstract}

Keywords: Awig-awig, Tri Hita Karana, Human Resources

\section{INTRODUCTION}

Nation of Indonesia constitutes a large nation having diverse kinds of customs and cultures that are unvaryingly distributed in each of its province. These cultures are then inherited, interpreted, and realized in line with the processes of social change that take place in society. Realization of values of these cultures represents the manifestation and legitimacy of society through the culture. In turn, the existence of culture and the diversity of the noble cultural values possessed by the Indonesian people serve as a means of building the character of the citizens, both related to private and public character (Yunus, 2014). In addition, a developing culture will become a benchmark for Indonesian culture that is inseparable to the influence of local culture that has emerged since the pre-Hindu era. Formation of such a local culture is inextricable from local genius roles that shape the colors and nuances of Indonesian national culture, that is to say, the formation of local culture is made up of three main characteristics. Firstly, the formation of culture does not release local elements; secondly, it involves blending with religious culture (Hinduism, Islam, and other religions); and thirdly, distinctive personality of a nation, both which can be observed in a limited (local) manner or that which can be observed nationally (Lestari, 2000), in which it is the forerunner to the formation of local wisdom itself, is a view of life and science and life strategies applied by local communities in answering various problems in meeting their needs. Local culture is also often associated with local wisdom, local knowledge or local genious (Fajarini, 2014). Globalization bringing about the impacts of "world without borders" makes people connected to one another regardless of distance and time. Globalization also brings influences to foreign cultural lifestyle which refers to material satisfaction. The younger generation today will deem their 
existence is recognized more and looks cooler if they are able to have small talks at fancy places, wear fashionable clothes, get lots of likes on social media, and shop for branded goods that only certain people can afford to buy. In other words, the current generation can tend to feel great and valuable not because of personal qualities, but because of wealth (material) prominently. Such a kind of generation by Erich Fromm is called having oriented, not being oriented. An obsessive person always pursues wealth and status but is apathetic to developing moral qualities. In fact, actualizing human values requires a life struggle, and thus one will feel being more valuable and happy when they are able to achieve non-material happiness, such as intellectual happiness, aesthetic happiness, moral happiness, and spiritual happiness (Jalaluddin, 2012). It is inevitable that Indonesian culture could be carried away by the times due to the current millennial generation life styles, including in Bali. In addition to preferring to pursue something that is materialistic (hedonism), this kind of generation behavior will certainly have an impact on the Westernized millennial mindset such as adhering to atheism, being agnostic and tendency to prefer their individualistic characteristics to mutual cooperation. As a consequence, it can lead to erosion of cultural values and a decrease in the sense of selfconfidence in the natio's own culture (Surahman, 2013). Admittedly, culture that is extracted from local culture does not bring about an obstacle to progress in the global era, but instead becomes a cultural filter and an extraordinary-transformational force in achieving national greatness. Accordingly, exploring the values of local culture acts a strategic effort for national character building in the global era (Wagiran, 2012). The key to cultural conservation lies in the intention and enthusiasm of young generation to continue to preserve and for previous generations to indocrinate the following generations in what they know about the country's culture, history and traditions. As early as possible, the people of Indonesia, including Balinese themselves, must sincerely be assiduous in learning local languages and local dances and watching traditional performances or traditional ceremonies and the like, so that their love for culture sustainably grows and develops (Agustin, 2011).
Reporting from Beritabali.com, Denpasar, decline in the interest of Balinese youth in the preservation of Balinese culture and customs is starting to be intensely alarming; it can be seen from the decline in the number of new students registering for cultural studies programs. The phenomenon was revealed when Governor I Wayan Koster received a group audience from UNHI (Universitas Hindu Indonesia) Denpasar, Friday (14/9/2018). In point of fact, when examined further, the empowerment of awigawig implementation, which is based on Tri Hita Karana and noble values, encourages people to have more advanced mindset and experience a more dignified level of inner satisfaction as well as humanize the people. Furthermore, instancing from BaliBisnis.com (13/11/2018), I Wayan Koster, the Governor of Bali, claimed that Bali could still be lucky because it had a good asset for character education, that is, local culture which if applied seriously will create superior human resources (HR) because character development in Bali will be actualized through two ways, that is to say, to shape identity and moral integrity. The draft of the is being made by a team of experts to build the character in Bali based on local wisdom values such as lontar, literature, as well as existing pitutur-pitutur in Balinese society passed down from their ancestors since ancient times.

One instance of local culture that still exists and remains sustainable in Bali is the Traditional Village of Penglipuran which practices the values of Tri Hita Karana. Tri Hita Karana itself is divided into three parts. First is Parhyangan which regulates human relationship with Hyang Widhi Wasa (God Almighty); the second is Pawongan which regulates the relationship between humans and humans themselves; and the third is Palemahan which regulates human relationship with the environment (Rindawan, 2017). In the Village of Penglipuran, all Hindu traditions passed down from their ancestors are still preserved since they shall be preserved by all levels of society as regulated in awig-awig. If there are community members who violate awig-awig, of course, they will be sanctioned according to the existing provisions. These sanctions are in the form of reprimands, money, social sanctions, customary sanctions and even expelling the perpetrators of the violations from the village. By empowering these customary law 
provisions, the people of Penglipuran Village have succeeded in building profitable tourism without eroding their cultural and traditional values and these cultural and traditional values are not disrupted by the negative impact of globalization.

A past study such as the one conducted by Lestari (2000) entitled "The Role of Local Genius in the Local Art" has revealed that the role of local genius is to realize the openness of structuralist and historical transformations which have a function to support the structuralism of new social groups based on balance of values and attitudes and solidarity according to common interests. A study conducted by Agustin (2011) entitled "Penurunan Rasa Cinta Budaya dan Nasionalisme Generasi Muda Akibat Globalisas" has also revealed that, on the one hand, globalization has negative impacts on the culture of the Indonesian nation. The method of control with the aim that only the positive side will be taken all of these impacts is to filter out the foreign cultures that enter Indonesia and preserve the national culture. Jalaluddin's (2012) study entitled "Membangun SDM Bangsa melalui Pendidikan Karakter" provides a new insight that education in Indonesia zrelies only on pronunciation and repetition alone that prepares material-based individuals, but does not develop the learning coverage to explore related matters to spiritual depths, natural intelligence, and freedom to explore things. Through holistic education, educational activity is not only a matter of teaching pronunciation and pursuing completion of subject matter, but is also a matter of exploring the natural talents and potentials of individuals as well as activating the individual's awareness until their character is formed maturely. Wagiran's (2012) study under the title "Pengembangan Karakter Berbasis Kearifan Lokal Hamemayu Hayuning Bawana (Identifikasi Nilai-nilai Karakter Berbasis Budaya)" exposes that Hamemayu Hayuning Bawana holds a comprehensive character dimension related to the development of the quality of human resources in their relationships with God, fellow human, and nature. Such a strategic role will bring about an optimal impact if accompanied by an appropriate implementation strategy. Educational institution as the main institution for human resource development have a strategic role and responsibility to formulate the precise strategy in internalizing these values. Surahman (2013) in her study entitled "Dampak Globalisasi Media terhadap Seni dan Budaya Indonesia" reveals that mass media serves as a usable means to help people face global currents. The mass media has the power of influencing people's thinking and behaviour for better or for worse. Thus, globalization will not undergo a rapid development in insolation from the role of the mass media. For this reason, the socio-cultural aspect of Indonesia as a national identity needs to be preserved. One way is by filtering foreign cultures that enter Indonesia and and preserving the local cultures of the nation.

Other findings of scientific studies similar to those found by these past studies include the finding of a study conducted by Fajarini (2014) entitled "Peranan Kearifan Lokal dalam Pendidikan Karakter". The study discovers that by exploring and preserving various elements of local culture, local traditions and institutions, including useful norms and customs, the culture can function effectively towards character education, as well as by conducting studies and enrichment of new cultures. The aim is that the existing local wisdom values are not lost to the times but become the character of the Indonesian nation. Yunus (2014) in her research entitled "Nilainilai Kearifan Lokal (Local Genius) sebagai Penguat Karakter Bangsa, Studi Empiris tentang Huyula" discloses that Huyula's local culture contains the values of Pancasila which serve as the basis for the nation's character development. Hence, if the transformation process of Huyula's local wisdom values can be realized in appropriate manner, the development of the national character, especially in the Cityo f Gorontalo, will be realized. Hafid, Rosdin, \& Soselisa (2015) in their paper entitled "Pendidikan Multikultural Berbasis Kearifan Lokal: Falsafah Kalosara dalam Masyarakat Tolaki" exposed an understanding and insight that, in its dynamics the people of Tolaki inhabiting the Southeastern Peninsula of Sulawesi Island have a customary instrument that regulates all patterns of community behaviour called kalosara. Kalosara as the main instrument for the order of people's lives to date still exists and is maintained by all levels of society, especially in the life of socio-culture. Thus, along with the development of the dynamics of people's lives which are increasingly complex 
and give rise to various problems, including at the political and economic sector, the presence of kalosara as an instrument of solution necessarily needs to be maintained and developed. The research of Rindawan (2017) entitled "Awig-awig dalam Melestarikan Adat dan Budaya Bali" reveals that the function of awig-awig as a social control for the people in Bali is to take control of the mindset, attitude patterns and actions of community members so as not to commit things that are negative in nature that even destroy the customary order which then have the potential to lead to shocks to the society. The role of awig-awig in maintaining the customs and culture of the Balinese people transforms into maintaining the life order of the Balinese people to remain sustainable in the religious, cultural, and socioeconomic sectors through the preservation of customs and culture based on the concept of Tri Hita Karana. Andayani \& Edhi Martono (2017) study entitled "Pemberdayaan Masyarakat Melalui Pengembangan Desa Wisata dan Implikasinya terhadap Ketahanan Sosial Budaya Wilayah (Studi di Desa Wisata Penglipuran Bali)" shows that Tourism Village of Penglipuran is one of the tourism villages in Bali which has an attraction in the form of village spatial patterns and distinctive traditional building architecture, quite unique customs, and natural wealth in the form of bamboo forests. Involving the local communities in the management of tourism villages is one of the efforts to empower the community. Expectedly, the community, government, and the head of the Traditional Tourism Village of Penglipuran management actualize their roles by always working together with each other to keep the traditional village always clean, charming, and sustainable and to continue to implement the noble values of the ancestors in order that it can continuously be passed on to the future generations since it has appeared as a bulwark for the entry of foreign cultural influences, especially those that are incompatible with local personalities. Wiguna (2018) in her research entitled "Memahami Pertalian Desa Pakraman di Bali dengan Karang Ayahan sebagai Bagian dari Palemahan berdasarkan Konsep Tri Hita Karana" found that the existence of Karang Ayahan veritably depends on the existence of a Pakraman village. For krama (community) of the village, territory is a crucial part of the sovereignty of a Pakraman village community that shall be maintained. Therefore, Karang Ayahan should not be exiled without obtaining approval from the highest decision-making institution concerning principle and strategic matters in the village of Pakraman called Paruman.

Based on the research background that has been described, this study examines how awig-awig stimulation is realized in developing character and improving human resources in Traditional Village of Penglipuran. The specific purpose of this study is to reveal the stimulation of awig-awig in developing the character and improving the human resources in the Penglipuran Traditional Village. The theories that support this research are Theodore $\mathrm{M}$. Newcomb's theory of personality and culture, Bronislaw Malinowski's theory of functional culture, and theories related to local wisdom and human resources.

\section{METHOD}

This research was conducted in the traditional village of Penglipuran from November 2019 to October 2020. To answer research questions, in-depth interviews were conducted with several informants who were considered to have good knowledge about awig-awig and were involved and played a role in its implementation in the village. Each interview was conducted for an average of one hour. By referring to the concept of Afrizal M. A. (2017), data collection was carried out using in-depth interviews, document collection and semi-involved observation. The interview process was recorded with an audio recorder under the consent of the participants. Therefore, the data were collected through various processes, such as interviews, documentation studies and observations, and data presentation.

The data of this research were analyzed through four flows of analysis activity, such as data collection, data reduction, data display and conclusion drawing / verification. The validity tests of the data in this study includes credibility test, transferability test, dependability test, and confirmability test. The informants in this study are as follows:

Table 1.

List of Informants, 2020

\begin{tabular}{|c|l|}
\hline No. & \multicolumn{2}{|c|}{ Informant } \\
\hline 1. & $\begin{array}{l}\text { Bandesa Adat (Head of Balinese } \\
\text { Traditional Village) of Penglipuran }\end{array}$ \\
\hline 2. & Chairman of Traditional Tourism \\
\hline
\end{tabular}




\begin{tabular}{|c|l|}
\hline \hline & Management of Penglipuran \\
\hline 3. & $\begin{array}{l}\text { Chairman of Traditional Cultural Festival } \\
\text { of Penglipuran }\end{array}$ \\
\hline 4. & $\begin{array}{l}\text { Indigeneous Community Members of } \\
\text { Penglipuran }\end{array}$ \\
\hline
\end{tabular}

The study uses a qualitative research design and purposive sampling technique in determining informants. Sugiyono (2018) states that purposive sampling is a sampling technique to select informants as the data source with certain considerations. Certain considerations meant for the research comprises selecting informants who are considered to have good knowledge and deep understanding of the object under study, or those who may be the rulers so that it will make it easier for researchers to explore the object / social situation under study (Sugiyono, 2018). Addition of samples would be ended when the data collected is saturated from various informants, both old informants and new informants. Taylor \& Bogdan (1984) claimed that collection of data is considered saturated when the data obtained by researchers has found nothing novel anymore. In this qualitative research, "information gathering" is carried out by the variety of existing variations, not from the number of samples of data sources. However, all components must be represented in order to obtain broad and varied data.

\section{RESULTS AND DISCUSSION}

Results of the data analysis of this study indicate that all interviewed informants have an understanding and knowledge of awig-awig of the village of Penglipuran. Furthermore, this study provides an overview of how awig-awig stimulation has the power of developing character and improving human resources based on Tri Hita Karana in the traditional village of Penglipuran without being eroded by globalization, but sustainably progressing to become a well-known and profitable tourism village for all people without eliminating culture and local traditions. The following presents a further explanation for each awigawig stimulation in developing character and improving human resources in the village of Penglipuran based on the concept of Tri Hita Karana.
Stimulation of Awig-Awig in Character Development in the Traditional Village of Penglipuran

As previously explained, the traditional village of Penglipuran adheres to the concept of Tri Hita Karana which is the philosophy of every traditional village in Bali. The philosophy consists of three parts, specifically; (1) Palemahan (maintenance of a good relationship with the environment), (2) Pawongan (maintenance of a good relationship with humans) and (3) Parhyangan (maintenance of a good relationship with God). The present research found that Bendesa Adat verbalized that the three pillars of Tri Hita Karana are implemented in everyday life, such as for forest maintenance careless cutting down of trees is prohibited (palemahan), in the marriage system community members are prohibited from practicing polygamy (pawongan), and every member of the community shall carry out rituals / prayers according to the existing rules (parahyangan). All activities carried out by the community of Penglipuran Village, since their own spirit comes from Tri Hita Karana, distinctly aims to protect all the community members in order that a harmonious family can be created; the vision is Hita and the mission is Karana which is imbued with awig-awig. The implementation of the Parhyangan value as well as the Pawongan value transforms into celebration of holidays or implementation of traditional ceremonies. Awig-awig itself contains rules that shall be applied to achieve goals where culture is the breath and the manifestation is through ceremonies to maintain peace in the village.

This is in line with the provisions of awig-awig in Article Two regarding proportion and inauguration in the village of Penglipuran which reads: The entire community members of the traditional village of Penglipuran: (1) strengthen and preserve the values of Hinduism, (2) strengthen all forms of awigawig, (3) maintain the peace in the village and its community members both in the real world (sekala) and in the unreal world (niskala). This statement is supported by the statements given by one of the community members of the traditional village of Penglipuran who explained the marriage process in the village. The informant said, "Uniquely, if there is a community member holding a wedding ceremony here, kentungan is sounded to all residents as a medium for announcement that 
there will be a wedding ceremony. The sound of the kentungan must be subtle, because each sound rhythm has a distinguished meaning. The wedding ceremony is held in their respective gardens, and in Kahyangan they are obliged to pay in the form of a tumbakan according to customary decisions. This is so that the ties to the ancestors in our village are not broken." This statement is in accordance with the awigawig provisions in Article Twenty Three Number Two, which reads "If one of the villagers is married, the sound of kentungan kulkul must be soft as a sign that the community members have paid for the tumbakan according to the customary decisions. Of course, this event is an example showing the values of Parhyangan and Pawongan which synergize with each other. The two are interrelated where humans have an important role to play in the success of a sacred ceremony as prostration and devotional service to God Almighty with the aim that the village remains free from disturbance both in sekala and niskala.

Bendesa Adat then explained about this by saying "Here we are applying the concept of Karang Memadu. Community members of this village are prohibited from practicing polygamy. There are sanctions for those who violate it, such as the perpetrators will be placed in the pekarangan memadu and ostracized by the community. Their rights in the village may be still the same as those of other members of the Penglipuran, but of course there are rights that are revoked, such as not being allowed to pray at the Pura Kahyangan (place of worship) in the village. What is hard for the perpetrators here is that if they want to carry out social activities, they will not be able to do so because they do not interact with local community members as a result of the exile punishment they are currently undertaking. The law is permanent as long as community members commit polygamy, but if they practice the polygamy and only have one lawful and customary wife, they will be released from the pekarangan memadu. The origin of the formation of Karang Memadu itself is from the village of Bayung Gede. As previously explained, the village of Penglipuran adopts a culture that is inherited from its origin, and this is the proof that the village community members reminisce about the ancestral culture (culture inherited from the mother)."
The statement is in accordance with the provisions of awig-awig in Article Thirty-Nine which reads: "Everyone is leteh, such as: children without parents, women who are pregnant but no perpetrator acknowledges, and people who are caught committing cheating." This is followed by heavy customary sanctions after they have finished becoming community members of the village, which is regulated in Article Thirteen Point Three which reads: "People who is no longer becoming villagers do not get parts of what belongs to the village or banjar", and then strengthened by provisions in Article Fifty-five Point Six which reads: "If there are indigenous villagers, both men and women, who practice polygamy, they shall be subject to fines according to the applicable rules." Not only that, it also turns out that village of Penglipuran groups its community members into certain groups as determined in Article Five of awig-awig and the mention of the hulu apad community system in Article Fourteen. As for Article five, it reads: "The indigenous villagers are divided into three groups: (1) Pengayah Arep, (2) Pengayah Roban, and (3) Pengayah Deha Teruna, and others follow customary rules, each of which can be understood based on the statements of one of the community members of Penglipuran who said: 'Pengayah Arep refers to the head of the family who is responsible in one Karang Kerti (the yard of a house)'. Pengayah Arep refers to those who have full responsibility regarding the traditional customs of Penglipuran. Pengayah Roban refers to those listed on the family card and joined in one of the organizations in the village such as gong sekaa, sekaa baris, sekaa peratengan, and sekaa pecalang. For community members who are married and are members of the sekaa teruna, they will join the roban pengayah organization that I mentioned earlier. The roban pengayah has a role, namely to help accelerate the process of cultural activities carried out in the village of Penglipuran. Meanwhile, Deha-Teruna refers to a group of young people who are not married. The community groups in Deha-teruna are obliged to assist all activities that take place in the Penglipuran village."

The informant explained, "It is a system of division of duties in the ceremonies held here. In this village there is no Ida Pedanda or Jro Mangku but Jro Bayan. Members of the community here must always ask Jro Bayan for 
directions if they are going to hold a ceremony. Everything that Jro Bayan needs is prepared by Jro Bahu. Everything that Jro Bahu needs is prepared by Jro Singgukan. Meanwhile, Jro Cacar is in charge of distributing the offerings needed for the ceremony. Jro Balung's duty is to find ingredients for making the offerings and they certainly have to make sure which ceremony applies chicken or pork. Jro Pati also plays a role in preparing offerings, but the others perform the activity of cutting chicken, meat or beef. From either Jro Balung or Jro Pati, there must be a representative to assist community members in preparing the offerings to ovoid mistakes. But, why do they have such a title? In fact, penghulu apad means being pushed from the bottom up. Jro Bayan is in number one, Jro Bahu is in number two, and Jro Singgukan is in number three. The village of Penglipuran has 77 family members. Jro Bayan will retire when he has a child and his child will be in 77 th position. The calculation is based on the length of time a community member have been the member of the village of Penglipuran. Each hulu apad community member is obliged to take notice whether: their youngest child is married, one of their grandchildren is married, their child is getting older but is not married, and the rest must go according to the rules. An explanation of this provision is obtained through a statement of one of the informant who says: "These are the conditions for entering the hulu apad group. In addition, there are other requirements, namely everyone who belongs to this group shall be married, not physically disabled, and physically and mentally healthy. If any member of the group dies, they are replaced by the members in the sequence number below. If there is Jro Bayan who gets divorced from their partner, they are also replaced by a member of the sequence number below. They will be permitted to re-enter the hulu apad group if they meet all the necessary requirements."

The articles mention about this include Article Twelve which stipulates about fines, Article Twenty which determines the rules for meetings, Article Twenty-four which regulates the rules for sounding the kulkul, Article Twenty-eight which regulates the karang kerti, Article Thirty which regulates four-legged animals, Article Twenty-three which regulates environmental communities, Article Forty-four which regulates burial of corpses, Article Forty-six which regulates the rules for using graves, Article Fifty-two which regulates catur brata penyepian, Article Fifty-three which regulates pecaruan, Article Fifty-five which regulates the act of eloping, Article Fifty-six which regulates divorce and Article Sixty-three which also regulates about fines. To deepen understanding regarding the sanctions in question, statements from an informant is presented below. The informant verbalized "People here have to think before performing any action. Sanctions imposed are not merely a matter of money; it is a matter of shame, especially involving mental problems. Suppose, I have bought alcoholic drinks from my brother and I get drunk. Let's say the place where I'm getting drunk is the stall of one of the villagers. If there are members of the community who know about the incident, of course I will be reported to the prajuru adat (a customary village leader). Ironically, it is not only me who will be sanctioned, but the stall owner and the brother will also be affected. The sanctions I will receive are performing the ritual ceremonies at my own sanggah, the Pura Kahyangan, the stall or the place where I got drunk at, and the house where we live. Carrying out such a ceremony alone consumes about twenty-five chickens, and it's still only chickens. Not to mention, as the perpetrator, I have to provide offerings of pejati and other praying facilities. The religious rituals that I will perform must be in the presence of official village and customary village administrators. Otherwise, my delinquency redemption process is deemed legally incompleted. The point is related to the violation of customary norms that occur in Penglipuran village, each perpetrator and their family are prohibited from entering the temples in the village because they are considered leteh. In addition, the perpetrator and his family do not receive customary or official services form the village. Therefore, when there is one member of the community is commiting an act that breaks the rules, the other members of the community just need to scream "Beware! You can be subject to customary sanctions" The perpetrator must immediately stop doing so. This also applies to the community members of Penglipuran who live outside the village. If they live in Denpasar and are caught drunk, then one reports them to the village, they will definitely be sanctioned." These informant's statements are confirmed by Bendesa Adat's statement saying, "In this village, the community has held the principle 
that rules are not to be broken, but to be obeyed. The realization of Tri Hita Karana's vision and mission is through the success of the community members in obeying the existing rules in the Penglipuran Village itself. The matter of the violation is number two. In the village, community members also highly value shame, and shame must be taken notice of in each individual. Community members here do not take social stratification into account in equalizing the imposition of sanctions for acts of violation of customary rules. So there is no view of who is the perpetrator of a delinquency; whether they are the children of an official, director, boss, or the like."

Stimulation of awig-awig in the value of palemahan is revealed through the informant's statement in the quote: "In this village, the villagers raise livestock such as cows, chickens and pigs, but their placement is regulated. For instance, pigs are in teba (the back yard of the house with a bush), so that the house remains clean. This is a tourism village where the houses of the residents may be entered by tourists; and therefore, we always keep our houses clean and odorless with livestock manure. It has also been prescribed in awigawig that is regarding how livestock must be placed and cared for by residents who raise them." The statement is regulated in Article Twenty-nine Part Two of Awig-Awig which reads: "All villagers who raise four-legged animals must be ready to be ordered to tie and cage their four-legged animals so as not to damage and even disturb the land or gardens of other villagers, especially if the animal in question enters or litters Kahyangan", and Article Thirty which reads: "Procedure for raising a four-legged animal: (1) if a fourlegged animal is released from its cage, the owner will be fined if the animal: (a) causes damages to land or gardens etc., (b) enters into Kahyangan, the penalty is the owner of the animal is subject to a ceremony to clean the Kahyangan, (2) the owner wo raise a fourlegged animal shall; (a) meet the village administrator, (b) raise the four-legged animal in the manner applicable according to customary rules, (3) raising a four-legged animal can be said: (a) the raiser is required to pay fees to the administrator according to the customary rules, (b) If there are no residents who admit that the animal that is released from its cage is raised by them, the animal can be owned by the customary village administrators after a month in the cage, until one recognizes it as theirs. Other palemahan values the researchers found can be seen from the statement of the Head of the Tourism Village of Penglipuan who said "The villagers are indeed obliged to plant mutually-agreed upon plants in front of their respective houses. These are things that must be done in order to make visiting tourists feel at home to stay for a long time in the village. Besides, as far as the eye can see, the village of Penglipuran still looks lush and beautiful with flowers growing along the road." Regarding this, it is also regulated in Article Thirty-three of Awig-Awig concerning Environmental Community which reads: (1) All residents of Penglipuran traditional village are not required to visit the place where people passed way, do littering, pollute the environment or others that cause damages to the beauty of the village of Pekraman, (2) The front side of karang kerti ditch shall be protected and planted with various types of flowers, it is prohibited to plant other types of plants that cause the environment along the road to be unappealing, and (3) Whosoever does not comply with it, they will be fined according to the applicable rules as stipulated in awig-awig.

Article Twenty-Eight of Awig-Awig, which regulates the residence of residents and their environment, is realized in a situation described by one of the informants who said: "The uniqueness of living side by side with neighbors in this village includes the position of the roof of their house up to our yard. When it rains, the water pouring from the roof of their house falls on our house. Likewise with our yard; the roof touches parallel to my neighbor's yard next door. When it rains, the rain water poures down to my neighbor's yard; whereas, regarding that matter it has been regulated and specified in awig-awig. If the same condition happens outside of this village, it will cause offense between the neighbors. To overcome the water pouring from the roof so as not to stagnate, we made a songbah. Thus, rainwater from the roof will not stagnate in our yard. Of course this must be discussed with neighbors so as not to disturb each other. If negotiations with neighbors do not meet a mutual agreement, the customary committee will help us in building a karang kerti. In addition, songbah is beneficial for the surrounding environment because it makes the yard clean and the water is absorbed by the soil quickly." In addition, the Head of 
the Management of the Tourism Village of Penglipuran also said: "Even so, our land needs to be cultivated properly, and because of that we installed septic tanks and biopore. It would be even more effective if the wastewater uses biopores added with organic substances so the soil becomes more fertile. Biopore is a water reserve hole, but it cannot clean water. I think that's what we need to improve later."

Subagia (2016) expresses the basic concept of Tri Hita Karana and if examined from the basic concept of natural law dialectics as described above, it will include the following:

- A harmonious relationship between humans and Ida Sang Hyang Widhi Wasa (God Almighty),

- A harmonious relationship between humans and their fellows, and

- A harmonious relationship between humans and their environment.

Through the description above, it can be understood that community members of the Traditional Village of Penglipuran represent a devout community member who highly upholds the cultural heritage of their ancestors from their ancestral village, which is the village of Bayung Gede. The culture inherited from the Bayung Gede village is entirely applied in every aspect of life in the Traditional Village of Penglipuran. It in line with what has been mentioned by Wagiran (2012), who argued that exploring local cultural values was a strategic effort in building the character of a nation in the global era. The key to cultural conservation lies in the intention and enthusiasm of young people to continue to preserve and the previous generations teach what they know about the cultures, histories and traditions to the next generation.

\section{Stimulation of Awig-Awig in Human Resources Development in the Traditional Village of Penglipuran}

Stimulation of awig-awig in improving human resources in the traditional village of Penglipuran is more directed at the efforts made to form qualified society who own skills, work capablities and work loyalty to organizations that have been formed in the village. Besides, human resource development that must be undertaken is through education. As an effort to realize the increase in human resources, the traditional village of Penglipuran holds a cultural festival which lasts for approximately 1 (one) month at the end of the year. Essentially, the festival is regularly held in the village to commemorate and enliven the village with the aim that it remains "steady and reminiscing" of its heritage culture. The reason behind the implementation of the cultural festival was explained by the Head of the Tourism Village Management of Penglipuran saying: "In fact, the vision of the tourism village of Penglipuran is a community-based tourism village, cultured and environmentally sound based on the philosophy of Tri Hita Karana; the vision then descends into the mission and the mission is translated into goals; goals are translated into targets and targets are directed into strategies to actualize the vision and mission. In this village, the community acts as a subject, not as an object. What we mean by 'subject' is society can increase its welfare through its respective functions and roles."

On that account, the empowerment of human resources in village of Penglipuran is transformed into an effort to make each individual aware of their role and responsibility for the sake of the effort to make the village a developed village as well as a the one that maintain traditions and cultures passed down by the ancestors. One way is by applying the Tri Hita Karana concept which basically has also been regulated in awig-awig as well as the activities of customary village organizations. The articles of awig-awig regulating about tis are Artcile Eight which reads: "All indigenous villagers who are in charge of performing ngayah: (1) ayah ngarep who comes from the community of traditional village of ngarep, (2) ayah roban who comes from the community of ngayah roban, (3) Ayah Deha-Truna who comes from the youths of the village", and Article Nine which reads; "The obligations of indigenous villagers are: (1) every member of the indigenous village community must comply with the contents of the consensus rules and customs / habits, which are in accordance with the rules of the customary village, (2) the indigenous villagers who are assigned the task of ngayah shall prepare them as complete as possible, (3) indigenous villagers who are assigned the task of ngayah shall execute the preparation of necessities in accordance with the applicable rules and regulations, and (4) other matters shall be executed in accordance with applicable agreements and regulations. Hence, the holding of this cultural festival 
involves all groups of traditional village communities without exception in the execution of ngayah activities to actualize their respective roles and responsibilities by preparing as completely as possible everything needed. The purpose of holding a cultural festival is to preserve physical and non-physical culture. Additionally, cultural festivals can be used as a promotional event. This indicates that there is a tendency to make community members reminisce about the culture that lives in their environment.

Organizing a cultural festival, in addition to making the next generation eling (reminisce) of their culture, is also a learning arena to train soft-skills while at the same time increasing kinship ties between all elements of society. Contribution of the cultural festival in the traditional village of Penglipuran was conveyed by the Chairman of the Cultural Festival Committee who said "The implementation of cultural festivals is intended to cause future generations to remain eling (reminisce) about the cultural heritage of their ancestors. It is as well as the meaning beyond the name Penglipuran village itself, which is "bearing in mind the temples of the mother's village". Furthermore, we deliberately raised a theme about history in order that all people would be educated. On top of that, a cultural festival also appears as a learning medium to preserve the living awig-awig in this village. Important and vital contributions from holding a cultural festival include:

1) to increase the creativity of the artists

2) to improve the village economy for the welfare of its people

3) to assist the government in fostering tourism activities

4) to promote the village of Penglipuran to the outside world

Therefore, this event is present as an activity that plays a very crucial role in the village. The community members in the village play an important role in realize their responsibilities to make this event a success. Everything that is done requires good cooperation. Perhaps the community members do not call to mind the importance of this activity because each enjoys performing the activity on their own part. So, the term is ngayah ring desa; each performs their activities voluntarily. Thus, ngayah can train cooperation and improve kinship as well as helping village and even government work to make the tourism run well."

In addition to cultural festivals, empowerment of human resources improvement is through social culture in the Village of Penglipuran. The social culture in question refers to the process of social interaction from small things such as the formation of personalities (social experience) as well as the educational process and the introduction of the cultures of Penglipuran village to children. Bendesa Adat explained "As part of the residents of this village, everyone is required to enter into one of the sekaa in the village. What is required in the group, which will become a reflection to determine which group is more appropriate for them to enter, is their job desk. Sekaa is a socio-cultural organization that functions as a forum for cultural preservation and contains philosophical values such as kinship, cooperation and attachment. Each 13-year-old aged community member having graduated from elementary school is required to enter the group. All adult members of the community have joined the group. Meanwhile, the process of educating children in the village of Penglipuran, one of which is through preservation of Balinese language and script, is followed by children. In organizing the past cultural festival there have been competitions about local culture that involve the participation of children. The lessons they get from school and when they are teenagers vary. They will get other lessons from their truna groups later. Regarding that, it all returns to Regional Regulation Number IV of 2019, which in essence is to preserve the socio-cultural scope with the purpose that the next generation remains aware of their ancestral cultures." Bendesa Adat also explains things alike by saying "On the other hand, of course in the effort to preserve ancient cultures, of course we encounter obstacles, especially in the era of globalization. The younger generation will continue to exist and live in different era, and what's more, this is a tourism village where the people who come have different cultures. If this village does not have a fortress by telling stories and providing explanations related to ancestral culture to future generations, it is possible that the original personality (character) of the indigeneous inhabitants of the village will be eroded. However, because education and provisions have been given as early as 
possible, future generations have the capability to interpret the cultures and values that have been implanted in them. This village already has a Balinese language and script preservation program, the implementation of which is to provide Pesraman village. Thus, this village also applies a principle "Sesanu manuk linggih" (shall be ready to take command). There is no view that someone is the son of a state official. There is no attitude of looking at the social status in the case that one with high social status only commands orders. Each is obliged to directly participate in performing activities. An official of Regional People's Representative Council dances at the temple is a common fact in this village. When we have been given perfection, it must be used as a means of devotion to God Almighty."

Bendesa Adat continued, "Let me take an example from my experience as a Bendesa Adat. I caught one of the Penglipuran Village youth. She rarely stays at home and returns to her hometown. As soon as she performed ngayah in the village, she was told to bring a gebogan sari by upholding it on her head. Instead, she preferred to carry it on by hand instead of putting it on her head to avoid her hair, which had been styled in the salon, from a mess. Ironically, she even told a friend of her who only had an elementary school to pick the gabongan sari up. As a Bandesa Adat, I then rebuked her in a loud-sounding way and gave her a personal advice. I explained to her that if she did not carry the gebogan sari by holding it on her head, she would not receive protection from me as the Bendesa Adat. Apart from that, I emphasized to the girl that when she gets married she will not receive the right as a resident of Penglipuran. To make the teenagers understand custom and social rules, they should be educated in that way."

Community members of Penglipuran village having been members of the organization group and organizational structure strive to always drive their village activities through positive activities, which results in the village environment to always be in a clean state because it is a form of real effort by community members to implement awig-awig mission to maintain the appealing nature of the village. Regarding this fact, Bendesa Adat explained, "In Penglipuran village, women members of PKK (Family Welfare Empowerment) also hold regular meetings in order to separate organic and non-organic waste in the first week of every month since 2014. In addition, the village collborates with Garbage Bank. So, organic waste is managed into compost, while non-organic waste can be recycled into new items that have a sale value."

Not only that, the bamboo forest, which is one of the natural wealth of Penglipuran village, is cultivated in a slash-select-crop system, and bamboo in the village is utilized as the roof of the houses of community members. Regarding this matter, Bendesa Adat explained "Bamboo forest owned by the village has been around since the Penglipuran village itself was formed; the factor is the geographical location of the village which is fertile making the bamboo plants grow fertile. Forty percent of the territory of the Penglipuran village is covered by bamboo. Therefore, most of the traditional houses of these villagers were processed from the roof of the bamboo armor. The house construction also applies the environmental concept. Why is that? The reason is the same as what is done in the village of Ambengan. The roofs of the houses in the village are made of ambengan. Back again to the topic of conversation about Penglipuran. Bamboo for the people in the village has ecological benefits. The ecological benefits can be seen from the condition that as a Balinese, everyone from a child is given a ceremony for cutting the umbilical cord using bamboo and when they die, everyone is made a kerandan made of bamboo. The economic benefit that we get is that bamboo stalks can be sold. "Then, the consequence if bamboo in the forest is cut down carelessly is as explained by Bendesa Adat who said "The traditional village is the owner of the bamboo forest. Therefore, if one wants to convert the function of the forest into a hotel, villa, restaurant or the like, it shall be done with the approval of the traditional village. However, if there are parties who insist on doing so without permission from the traditional village, their land will be revoked by the traditional village. If the community wants to cut bamboo, they are required to do it according to the slash-to-crop system which is a reflection of Palemahan values to make the forest sustainable."

Tracing further, the village of Penglipuran has a temple named Pura Ratu Pingit. Regarding the temple's existence, the Chairman of the Cultural Festival explained, "Ratu Pingit is associated with the community members of Penglipuran Village who are the 
people of Ida Bhatara Batur. Every time a Wali ceremony is exercised there, what is there as our area of origin, is also our duty here. At Pura Ratu Pingit is located an inscription stone storage. On the inscription on Ratu Pingit there is an inscription dating back to $1204 \mathrm{AD}$ and was found in around the 13th century." The same depiction was conveyed by the Head of the local Tourism Village Management who said, "Ratu Pingit is a temple, which used to be a storage area for gongs and inscriptions. When the Saraswati Day arrives, people performs praying at the temple. Apart from commemorating holidays, Pura Ratu Pingit is closed." Furthermore, one of Penglipuran community members commented on Ratu Pingit and said, "It is true that there is an inscription on the temple. It is said that from the inscription, this village's awig-awig was derived. However, to date, there has been no rereading of the inscription. Therefore, there is a recommendation that the inscription should be reread in order that young people know about it, and so it is not only parents who gain an understanding of it" The same was expressed by the Chairman of the Cultural Festival who said, "There has not been any rereading of the inscription written on Ratu Pingit. As far as I know, reading the contents of the inscription has only been done once. At this time, the customary officials want to hold a rereading activity, considering that this village is always visited by many academics from various backgrounds who are interested in researching the Penglipuran. Of course this will provide many benefits, both to the younger generation and the old generation, and including those who are often used as research sources so that in the future, we can provide detailed information. However, it is still in the planning stage wheasn it is still a pandemic situation, so it is not yet supportive to an execution."

Building upon the description above, Agustin's (2011) supports the idea that from an early age, Indonesians people, including Balinese themselves, must be active in learning regional languages and regional dances and watching traditional performances or traditional ceremonies to cause their love for culture to grow and develop. The traditional village of Penglipuran itself holds a cultural festival at the end of each year as a means of promoting the village outside as well as an effort to enable the younger generation to better recognize its cultures. Not only that, the implementation of the cut-select-crop system and the use of natural resources such as bamboo as roofs of houses, and the yard which must be planted with flowers as have been determined in awigawig to keep the Penglipuran village appealing must also be maintained and performed continuously. Livestock are placed in a cane, separate from the neighborhood of the residents' yards. It is intended to avoid the environment from pollution resulted from a bad odor from animal waste. Village land is filled with biopores to avoid flooding. Each house also contains organic and non-organic waste bins in order that they can be easily recycled as a result of the separation of the trash cans that have been carried out. Therefore, reliable human resources must be created because the human resources in the village of Penglipuran are able work hand in hand in working together to advance the welfare of the village community through an attitude that is always ajeg 'steady' and eling 'consciously reminiscing' which starts from oneself. Thus, cultured individuals who are not easily eroded by the current of globalization can be formed.

\section{CONCLUSION}

This study found the stimulation of awigawig upholding the values of Tri Sukerta in the form of Tri Hita Karana to develop character and improve human resources in the traditional village of Penglipuran is able to make people strong and aware of themselves. Thus, although the village is always crowded with tourists coming from various parts of the world with different cultures, the indigenous people of the village always reminisce about their truly original identity. In terms of Parhyangan, in maintaining a relationship with God, the traditional village community of Penglipuran always performs ceremonies according to traditional guidelines and existing provisions of applicable customary rules, such as not polluting sacred places and carrying out religious activities according to good days (adults) and mutual agreement. From the perspective of Pawongan, the community of the traditional village always maintains a harmonious relationship with fellow human, such as not committing fighting, not having an affair, and not regarding social status in community service in the village. Later this culture will have an impact on the formation of a blissfulness with the environment, 
considering that improving human welfare will manifest the values of Palemahan. Of these two values, with the attainment of physical prosperity in the world, humans should not forget to be grateful to the Supreme Creator who has again touched the value of Parhyangan. With the establishment of harmonious relationships with various parties, individuals who have a noble culture are formed. Therefore, it is also hoped that the life of the people who are "Moksartham Jagaditha Ya Ca Iti Dharma" can be achieved, that is to say, to achieve the goal of life in the form of happiness in the world and moksa (release or freedom from worldly attachment).

From the entire series of activities carried out to achieve the objectives of this study, the researchers are conscious of that with limited time, data sources, references and knowledge possessed by researchers, there must shortcomings which then belong to the researchers. On that account, further studies trying to reveal more scientifically satisfying results are welcomed. In this regard, several suggestions are given. Firstly, it is hoped that in the future the traditional village of Penglipuran will continue to live and its community members will always maintain the cultural heritage of their ancestors as their personal identity in particular and Balinese people in general as well as one of the assets the Indonesian nation owns. One way to do so is to re-read the history and the awig-awig which was derived from the sacred inscription of village heritage written on Pura Ratu Pingit. It aims to make the younger generation better understand and live up to their ancestral heritage. Secondly, to the old generation, they are encouraged to deepen their knowledge and be willing to become competent sources for those who want to explore historical information from their cultures so as to provide unbiased information, because many academics are interested in researching the traditional village of Penglipuran. The last but not least, it is hoped that all elements of society in the traditional village of Penglipuran will always adhere to the values of local culture to create both physical and spiritual happiness and prosperity.

\section{REFERENCES}

Afrizal M. A. (2017). Metode Penelitian Kualitatif: Sebuah Upaya Mendukung Penggunaaan Penelitian Kualitatif dalam Berbagai Disiplin
Ilmu. Depok: Rajawali Pers.

Agustin, D. S. Y. (2011). Penurunan Rasa Cinta Budaya dan Nasionalisme Generasi Muda Akibat Globalisasi. Jurnal Sosial Humaniora, 4(2).

Andayani, A. A. I., \& Edhi Martono, M. (2017). Pemberdayaan Masyarakat Melalui Pengembangan Desa Wisata dan Implikasinya terhadap Ketahanan Sosial Budaya Wilayah (Studi di Desa Wisata Penglipuran, Bali). Jurnal Ketahanan Nasional, 23(1).

Beritabali.com, Denpasar. 2018. Penurunan Minat Generasi Muda Bali akan Adat dan Budaya Mengkhawatirkan.

https://www.beritabali.com/read/2018/09/14/2 01809150002/Penurunan-Minat-Generasi-

Muda-Bali-Akan-Adat-dan-Budaya-

Mengkhawatirkan.html. Diakses 05 Juli 2019.

Cahya, Kahfi Dirga. 2019. Penglipuran, Desa Wisata Bali dengan Sederet Penghargaan. https://travel.kompas.com/read/2019/12/10/10 1700727/penglipuran-desa-wisata-balidengan-sederet-penghargaan diakses pada 08 Februari 2020.

Fajarini, U. (2014). Peranan Kearifan Lokal dalam Pendidikan Karakter. Sosio Didaktika: Social Science Education Journal, 1(2).

Hafid, A., Rosdin, A., \& Soselisa, H. L. (2015). Pendidikan Multikultural Berbasis Kearifan Lokal. Jakarta: Pusat Penelitian Kebijakan Pendidikan dan Kebudayaan Badan Penelitian dan Pengembangan, Kementerian Pendidikan dan Kebudayaan.

Jalaluddin. (2012). Membangun SDM Bangsa melalui pendidikan karakter. Jurnal Mahasiswa S2 Sekolah Pascasarjana, Universitas Pendidikan Indonesia, 12(2).

Komponen Desa Wisata. https://id.wikipedia.org/wiki/Desa_wisata. Diakses 11 Agustus 2020.

Lestari, W. (2000). Peran Lokal Genius dalam Kesenian Lokal (The Role of Local Genius in The Local Art). Harmonia: Jurnal Pengetahuan Dan Pemikiran Seni, 1(2).

Peraturan Daerah Nomor 4 tahun 2019. https://jdih.baliprov.go.id/produkhukum/peraturan/24744. Diakses 09 Maret 2020.

Rindawan, I. K. (2017). Peranan Awig-Awig dalam Melestarikan Adat dan Budaya di Bali. Jurnal Kajian Pendidikan Widya Accarya FKIP Universitas Dwijendra, 7(1).

Subagia, N. K. W. (2016). Persepsi Masyarakat terhadap Konsep Tri Hita Karana sebagai Implementasi Hukum Alam. Jurnal Fakultas Keguruan Dan Ilmu Pendidikan Universitas Lampung, 4(2).

Sugiyono. (2018). Metode Penelitian Kualitatif untuk Penelitian yang Bersifat: Eksploratif, Enterpretif, Interaktif, dan Konstruktif. 
Bandung: Alfabeta.

Surahman, S. (2013). Dampak Globalisasi Media terhadap Seni dan Budaya Indonesia. Lontar: Jurnal Komunikasi, 2(1).

Taylor, S. J., \& Bogdan, R. (1984). Introduction to Qualitative Research Methods: The Search for Meaning (II). New York: John Wiley.

Wagiran. (2012). Pengembangan Karakter Berbasis Kearifan Lokal Hamemayu Hayuning Bawana (Identifikasi Nilai-nilai Karakter Berbasis Budaya). Jurnal Pendidikan, (3).

Wiguna, M. O. C. (2018). Memahami Pertalian Desa Pakraman di Bali dengan Karang Ayahan Sebagai Bagian Dari Palemahan Berdasarkan Konsep Tri Hita Karana. Jurnal Panorama Hukum, 3(2).

Yunus, R. (2014). Nilai-nilai Kearifan Lokal (Local Genius) sebagai Penguat Karakter Bangsa. Studi Empiris Tentang Huyula. Yogyakarta: Deepublish. 